\title{
Identification and Characterization of Cannabidiol as an OX1R Antagonist by Computational and In Vitro Functional Validation
}

\author{
Rosa Maria Vitale 1,*(D), Fabio Arturo Iannotti 1,2 (D), Aniello Schiano Moriello ${ }^{2,3}$, Lea Tunisi ${ }^{2,4}$, \\ Fabiana Piscitelli ${ }^{1,2}$, Ranjev Savopoulos ${ }^{5}$, Luigia Cristino ${ }^{1,2}$, Luciano De Petrocellis ${ }^{1,2} \mathbb{D}^{\mathbb{D}}$, Pietro Amodeo ${ }^{1} \mathbb{D}$, \\ Roy Gray ${ }^{5}$ and Vincenzo Di Marzo ${ }^{1,2,6, *}$
}

Citation: Vitale, R.M.; Iannotti, F.A.; Schiano Moriello, A.; Tunisi, L.; Piscitelli, F.; Savopoulos, R.; Cristino, L.; De Petrocellis, L.; Amodeo, P.; Gray, R.; et al. Identification and Characterization of Cannabidiol as an OX1R Antagonist by Computational and In Vitro Functional Validation. Biomolecules 2021, 11, 1134. https:// doi.org/10.3390/biom11081134

Academic Editor: Vladimir N. Uversky

Received: 9 July 2021

Accepted: 28 July 2021

Published: 1 August 2021

Publisher's Note: MDPI stays neutral with regard to jurisdictional claims in published maps and institutional affiliations.

Copyright: (c) 2021 by the authors. Licensee MDPI, Basel, Switzerland. This article is an open access article distributed under the terms and conditions of the Creative Commons Attribution (CC BY) license (https:/ / creativecommons.org/licenses/by/ $4.0 /)$.
1 Institute of Biomolecular Chemistry, National Research Council (ICB-CNR), Via Campi Flegrei 34, 80078 Pozzuoli, Italy; fabio.iannotti@icb.cnr.it (F.A.I.); fpiscitelli@icb.cnr.it (F.P.);

luigia.cristino@icb.cnr.it (L.C.); luciano.depetrocellis@icb.cnr.it (L.D.); pamodeo@icb.cnr.it (P.A.)

2 Endocannabinoid Research Group (ERG), Institute of Biomolecular Chemistry, National Research Council (ICB-CNR), Via Campi Flegrei 34, 80078 Pozzuoli, Italy; aniello.schianomoriello@icb.cnr.it (A.S.M.); lea.tunisi@gmail.com (L.T.)

3 Epitech Group SpA, Saccolongo, 35100 Padova, Italy

4 Department of Veterinary Medicine and Animal Productions, University of Naples Federico II, 80131 Naples, Italy

5 GW Research Ltd., Sovereign House, Vision Park, Histon, Cambridge CB24 9BZ, UK; RSavopoulos@gwpharm.com (R.S.); RGray@gwpharm.com (R.G.)

6 Canada Excellence Research Chair on the Microbiome-Endocannabinoidome Axis in Metabolic Health (CERC-MEND), Université Laval, Quebec City, QC G1V 4G5, Canada

* Correspondence: rmvitale@icb.cnr.it (R.M.V.); vincenzo.dimarzo@criucpq.ulaval.ca (V.D.)

\begin{abstract}
The potential, multifaceted therapeutic profile of cannabidiol (CBD), a major constituent derived from the Cannabis sativa plant, covers a wide range of neurological and psychiatric disorders, ranging from anxiety to pediatric epilepsy and drug addiction. However, the molecular targets responsible for these effects have been only partially identified. In this view, the involvement of the orexin system, the key regulator in arousal and the sleep/wake cycle, and in motivation and reward processes, including drug addiction, prompted us to explore, using computational and experimental approaches, the possibility that CBD could act as a ligand of orexin receptors, orexin 1 receptor of type 1 (OX1R) and type 2 (OX2R). Ligand-binding assays showed that CBD is a selective ligand of OX1R in the low micromolar range $(\mathrm{Ki} 1.58 \pm 0.2 \mu \mathrm{M})$ while in vitro functional assays, carried out by intracellular calcium imaging and mobilization assays, showed that CBD acts as an antagonist at this receptor. Finally, the putative binding mode of CBD has been inferred by molecular docking and molecular dynamics simulations and its selectivity toward the OX1R subtype rationalized at the molecular level. This study provides the first evidence that CBD acts as an OX1R antagonist, supporting its potential use in addictive disorders and/or body weight regulation.
\end{abstract}

Keywords: orexin receptors; cannabidiol; molecular docking; molecular dynamics; calcium mobilization assay

\section{Introduction}

Cannabidiol (CBD), the main non-euphoric constituent of Cannabis sativa, exhibits a complex neuropharmacological profile, ranging from anxiolytic, anticonvulsive, and neuroprotective properties to analgesic and anti-inflammatory effects, all potentially useful for the treatment of several neurological and psychiatric disorders [1,2]. The molecular targets of CBD likely involved in its therapeutic effects have been recently reviewed $[3,4]$ and include, among others, the transient potential receptor channels (TRPs) TRPV1, TRPA1, and TRPM8 [5], the G-protein coupled receptors GPR55 [6], serotonin 1A receptor [7], and opioid receptors [8]. Moreover, even though CBD has a low affinity for the cannabinoid 
receptors, recent evidence indicated that it may act as a cannabinoid receptor of type 1 (CB1R)-negative allosteric modulator in some circumstances [9-11]. More recently, CBD has been also proposed as a therapeutic tool for addictive disorders such as drug and alcohol abuse [12-14]. In this view, the recent findings that the orexin system is involved in drug addiction [15], prompted us to investigate the orexin receptors, OX1R and OX2R, as possible targets for CBD. Both receptors are coupled with a $\mathrm{Gq}$ protein and their activation induces cell responses mainly via calcium $\left(\mathrm{Ca}^{2+}\right)$ - and diacylglycerol (DAG)-mediated pathways [16,17]. The endogenous ligands of these G-protein coupled receptors are two hypothalamic neuropeptides, orexin-A (OX-A) and orexin-B (OX-B), which regulate different physiological functions in mammals, such as sleep-wake cycles, energy metabolism, and feeding [18]. Both peptides arise from a common precursor, the prepro-orexin, a 130-amino-acid peptide. Orexin projections extend widely throughout the brain, innervating the neocortex, hippocampus, and forebrain structures implicated in the processing of arousal [19], wakefulness [20], feeding [21], emotion, and motivation [22]. Defects in the orexin system induce narcolepsy and catalepsy, whereas inhibitors of orexin receptors represent a promising therapy for the treatment of sleep disorders [23]. Orexin 1 and Orexin 2 receptors are differently distributed in the central nervous system (CNS), thus reflecting different biological profiles-while OX2R is mainly involved in sleep and arousal, OX1R is implicated in compulsive behaviour related to drug addiction and anxiety [24]. OX1R has a higher affinity for OX-A than OX-B, whereas OX2R binds both OX-A and OX-B with the same affinity [23]. In the present study, by performing binding experiments on both orexin receptors, we found that CBD binds OX1R selectively over OX2R. Then, by exploiting the recently-released $X$-ray structures of both orexin receptors $[25,26]$, the putative binding modes of CBD to OX1R were investigated by molecular docking and molecular dynamics simulations. Computational data, in addition to providing a possible structural basis for the observed binding, also allowed a rationalization of CBD selectivity toward the OX1R subtype. Finally, functional studies based on the measurement of intracellular calcium imaging and mobilization in OX1R-transfected Chinese hamster ovary (CHO) cells allowed the characterization of CBD as an OX1R antagonist.

\section{Materials and Methods}

\subsection{Radioligand Binding Assay on $\mathrm{CHO}$ Cells Expressing hOX1R}

Radioligand binding assays were carried out at Eurofins Cerep (France). Cell membrane homogenates $\left(20 \mu \mathrm{g}\right.$ protein) were incubated for $60 \mathrm{~min}$ at $22{ }^{\circ} \mathrm{C}$ with $0.1 \mathrm{nM}\left[{ }^{125} \mathrm{I}\right]$ orexin-A in the absence or presence of plant-derived CBD (GW Research Ltd., Cambridge, $\mathrm{UK}$ ) in a buffer containing $25 \mathrm{mM}$ 4-(2-hydroxyethyl)-1-piperazineethanesulfonic acid (HEPES)/ $\mathrm{NaOH}$ (pH 7.4), $0.5 \mathrm{mM}$ EDTA, $2.5 \mathrm{mM} \mathrm{CaCl}_{2}$, and $2.5 \mathrm{mM} \mathrm{MgCl}$. Nonspecific binding was determined in the presence of $1 \mu \mathrm{M}$ SB 334867. Following incubation, the samples were filtered rapidly under vacuum through glass fiber filters (GF/B, Packard Shelton, CT, USA) presoaked with $0.3 \%$ polyethylenimine (PEI) and rinsed several times with an ice-cold buffer containing $50 \mathrm{mM}$ Tris- $\mathrm{HCl}$ and $150 \mathrm{mM} \mathrm{NaCl}$ using a 96-sample cell harvester (Unifilter, Packard, Shelton, CT, USA). The filers were dried then counted for radioactivity in a scintillation counter (Topcount, Packard) using a scintillation cocktail (Microscint 0, Packard, Shelton, CT, USA). The results were expressed as a percent inhibition of the control radioligand specific binding. The standard reference compound was OX-A, which was tested in each experiment at several concentrations to obtain a competition curve from which its $\mathrm{IC}_{50}$ was calculated.

\subsection{Radioligand Binding Assay on $\mathrm{CHO}$ Cells Expressing $h O X 2 \mathrm{R}$}

Cell membrane homogenates $\left(20 \mu \mathrm{g}\right.$ protein) were incubated for $180 \mathrm{~min}$ at $22{ }^{\circ} \mathrm{C}$ with $0.04 \mathrm{nM}\left[{ }^{125} \mathrm{I}\right]$ orexin-A in the absence or presence of CBD in a buffer containing $25 \mathrm{mM}$ HEPES/NaOH (pH 7.4), $2.5 \mathrm{mM} \mathrm{CaCl}_{2}, 1 \mathrm{mM} \mathrm{MgCl}_{2}$, and 0.5\% BSA. Nonspecific binding was determined in the presence of $1 \mu \mathrm{M}$ OX-B. Following incubation, the samples were filtered rapidly under vacuum through glass fiber filters (GF/B, Packard) presoaked 
with $0.3 \%$ PEI and rinsed several times with ice-cold $50 \mathrm{mM}$ Tris- $\mathrm{HCl}$ using a 96-sample cell harvester (Unifilter, Packard). The filters were dried then counted for radioactivity in a scintillation counter (Topcount, Packard) using a scintillation cocktail (Microscint 0 , Packard). The results were expressed as a percent inhibition of the control radioligand specific binding. The standard reference compound was OX-B, which was tested in each experiment at several concentrations to obtain a competition curve from which its inhibitory concentration $\left(\mathrm{IC}_{50}\right)$ was calculated.

\subsection{Cell Culture, Reagents, and Transfections}

Chinese hamster ovary (CHO) cells were propagated in Dulbecco's modified Eagle's medium containing 10\% FBS, penicillin $(100 \mathrm{U} / \mathrm{mL})$, and streptomycin $(100 \mu \mathrm{g} / \mathrm{mL})$ in a humidified atmosphere at $95 \% \mathrm{O}_{2} / 5 \% \mathrm{CO}_{2}$ at $37{ }^{\circ} \mathrm{C}$. The day after plating, cells (at a confluence of about 70-80\%) were transfected with a plasmid carrying human orexin 1 receptor gene (Origene, IT; cat. n. RG210381). In parallel, a plasmid encoding for a scrambled sequence was used as control (Origene, IT; cat. n. RG) was used as the control condition. To generate stable clones, ORX1-transfected cells were selected using Dulbecco's modified Eagle's medium containing Geneticin (G418; $0.6 \mathrm{mg} / \mathrm{mL}$ ). After one month, the stable overexpression of the human OX1R receptor in $\mathrm{CHO}$ cells was measured by quantitative PCR (qPCR).

\subsection{Quantitative PCR for Clone Screening}

To quantify the OXR1 receptor overexpression in transfected $\mathrm{CHO}$ cells and thus select the more efficient clones, the RNA was isolated and purified from both control (not transfected) and OX1R-CHO clones. Quantitative PCR (qPCR) was carried out in a real-time PCR system CFX384 (Bio-Rad, Milan, Italy) using the SsoAdvanced SYBR Green supermix (cat. n. 1725274, Bio-Rad, Milan, Italy) detection technique and specific primers. OX1R forward: CGGAGGAAGACGGCTAAGATG; OX1R reverse: GCTCCCGGAATTTGCCACT; S16 forward: CTGGAGCCTGTTTTGCTTCTG; S16 reverse: TGAGATGGACTGTCGGATGG. Quantitative PCR was performed on separate clones. In addition, each sample was amplified simultaneously in quadruplicate in a one-assay run with a non-template control blank for each primer pair to control for contamination or primer-dimer formation, and the cycle threshold $(\mathrm{Ct})$ value for each experimental group was determined. A housekeeping gene (the ribosomal protein S16) was used to normalize the $\mathrm{Ct}$ values, using the $2^{-\Delta} \mathrm{Ct}$ formula; differences in mRNA content between groups were expressed as $2^{-\Delta \Delta} \mathrm{C}$, as previously described [27].

\subsection{Calcium Mobilization Assay}

$\mathrm{CHO}$ cells, wild-type or stably over-expressing recombinant hOX1R, were grown on $100 \mathrm{~mm}$ diameter Petri dishes as monolayers as described in Section 2.3. On the day of the experiment, the cells were loaded for $1 \mathrm{~h}$ at room temperature with the $\mathrm{Ca}^{2+}$ indicator Fluo-4-AM (Thermo-Fisher Scientific, Frosinone Italy) $4 \mu \mathrm{M}$ in dimethylsulfoxide (DMSO) containing 0.02\% Pluronic F-127 (Thermo-Fisher Scientific) in DMEM without FBS. After loading, cells were washed twice in Tyrode's buffer (145 mM NaCl, $2.5 \mathrm{mM}$ $\mathrm{KCl}, 1.5 \mathrm{mM} \mathrm{CaCl}_{2}, 1.2 \mathrm{mM} \mathrm{MgCl}$, $10 \mathrm{mM}$ D-glucose, and $10 \mathrm{mM}$ HEPES, pH 7.4) resuspended in the same buffer, and transferred, about 100,000 cells for each determination, to the quartz cuvette of the spectrofluorimeter $(\lambda e x=488 \mathrm{~nm}$; $\lambda$ em $=516 \mathrm{~nm}$ ) PerkinElmer LS50B equipped with PTP-1 Fluorescence Peltier System (PerkinElmer Life and Analytical Sciences, Waltham, MA, USA) under continuous stirring at $25^{\circ} \mathrm{C}$. Experiments were conducted by measuring cell fluorescence before and after the addition of the test compound at various concentrations. Antagonist behaviour of CBD was evaluated against the agonist orexin-A (Sigma-Aldrich, Merck, Darmstadt, Germany) $100 \mathrm{nM}$ by adding the test compound in the quartz cuvette $5 \mathrm{~min}$ before stimulation of cells with the agonist. The effect on intracellular calcium concentration $\left(\left[\mathrm{Ca}^{2+}\right]_{i}\right)$, exerted by the agonist alone, was taken as $100 \%$. Data are expressed as the concentration exerting a half-maximal inhibition of agonist-induced $\left[\mathrm{Ca}^{2+}\right]_{i}$ elevation $\left(\mathrm{IC}_{50}\right)$. Dose-response curves were fitted 
by a sigmoidal regression with variable slope. Curve fitting and parameter estimation were performed with GraphPad Prism ${ }^{\circledR}$ (GraphPad Software Inc., San Diego, CA, USA). Determinations were performed at least in triplicate. Statistical analysis of the data was performed by analysis of variance at each point using ANOVA followed by Bonferroni's test. The statistical significance of the antagonist effect was assessed with the Student's t-test. Statistically significant differences were accepted when the $p$-value was $\leq 0.05$.

\subsection{Calcium Imaging}

$\left[\mathrm{Ca}^{2+}\right]_{\mathrm{i}}$ was measured using the cell-permeable $\mathrm{Ca}^{2+}$ indicator, Fura-2AM (Life Technologies), dissolved in DMSO containing 0.02\% pluronic F-127 (Life Technologies, Waltham, MA, USA). The transfected cells, previously seeded on polylysine-coated coverslips (300,000 cells/coverslips and 10 independent passages), were loaded with $1 \mu \mathrm{M}$ Fura-2AM and $1 \mu \mathrm{M}$ sulfinpyrazone in serum-free medium for $20 \mathrm{~min}$ in the dark. The coverslips were placed into a perfusion chamber (Leica Microsystems $\mathrm{GmbH}$, Wetzlar, Germany) mounted on the stage of Leica digital microscope DMI6000 equipped with $\mathrm{CO}_{2}$ incubator cage (OkoLab, Burlingame, CA, USA), in order to provide saturated humidity atmosphere containing $95 \%$ air and $5 \% \mathrm{CO}_{2}$ at room temperature. For calcium recording, the cells were incubated in $500 \mu \mathrm{L}$ of an extracellular solution containing calcium $(145 \mathrm{mM} \mathrm{NaCl}, 2.5 \mathrm{mM} \mathrm{KCl}$, $1.5 \mathrm{mM} \mathrm{CaCl}_{2}, 1.2 \mathrm{mM} \mathrm{MgCl}_{2}, 10 \mathrm{mM}$ D-glucose, and $10 \mathrm{mM}$ HEPES, $\mathrm{pH} 7.4$ ) and perfused with each drug previously dissolved in the same solution. Observation and acquisition of images were performed with a 20X objective lens and carried out by appropriate speed filter wheels for $387 \mathrm{~nm}$ excitation-emission wavelengths (the peak excitation wavelength for calcium-free Fura-2), and $340 \mathrm{~nm}$ (the peak excitation wavelength for calcium-bound Fura2). Images were collected at different times for each drug, to achieve the best setting for every recording: every $5 \mathrm{~s}$ for the vehicle and every $1 \mathrm{~s}$ for orexin-A, for CBD (both $10 \mu \mathrm{M}$ and $20 \mu \mathrm{M}$ ), and ionomycin; then the images were digitized and analyzed using LAS AF 2.2.0 Live Data Mode software (Leica Microsystems, Leica, Wetzlar, Germany). An area on each sample free of dye-loaded cells was selected to determine the background fluorescence value to set the baseline value for analysis. The value of emission fluorescence obtained after $340 / 387 \mathrm{~nm}$ excitation was ratiometrically rendered as a measure of the cytosolic $\mathrm{Ca}^{2+}$ according to the formula $\left[\mathrm{Ca}^{2+}\right]_{\mathrm{i}}=\mathrm{KD} \times\left(F_{\max } / F_{\min }\right) \times\left[\left(R-R_{\min }\right) /\left(R_{\max }-R\right)\right]$ where $\mathrm{KD}$ is the dissociation constant for Fura2 $(140 \mathrm{nM})$ [28], $R$ is the experimental emission ratio, and $F_{\min }, R_{\max }, F_{\max }$, and $R_{\min }$ are the $380 \mathrm{~nm}$ fluorescence emission signals and emission ratio from $340 / 380 \mathrm{~nm}$ excitation at saturating and zero free $\mathrm{Ca}^{2+}$ levels, respectively. These values were automatically obtained by applying the software Leica MetaMorph (Leica Microsystems, Leica, Wetzlar, Germany Wetzlar) for calcium imaging.

\subsection{Computational Methods}

Starting ligand geometry was built with Ghemical 2.99.24 [29]. This structure underwent energy minimization (EM) at the molecular mechanics level first, using Tripos 5.2 force field parametrization [30], and then at AM1 semi-empirical level; fully optimized using GAMESS program [31] at the Hartree-Fock level with STO-3G basis set. The resulting conformer was subjected to ab-initio HF/6-31G*/STO-3G single-point calculations to derive the partial atomic charges required by the force field employed in molecular dynamics (MD) simulations (see below) by the Restrained Electrostatic Potential (RESP) procedure [32]. Docking studies were performed with AutoDock 4.2 [33], by using the crystallographic coordinates of OX1R and OX2R (PDB:4ZJC and 4SOV) as starting target structures. Both proteins and ligands were processed with AutoDock Tools (ADT), package version 1.5.6rc17, to merge non-polar hydrogens, calculate Gasteiger charges, and select the rotatable side-chain bonds. Grids for docking evaluation with a spacing of $0.375 \AA$ and $70 \times 60 \times 70$ points, centered on the ligand-binding site (gridcenters $-8.224,0.928$, -55.161 and $54.902,9.686,53.785$ for $4 \mathrm{ZJC}$ and $4 \mathrm{SOV}$, respectively), were generated using the program AutoGrid 4.2 included in Autodock 4.2 distribution. OX1R residues, Gln126, Gln179, and Asn318 and the correspondent OX2R Gln134, Gln187, and Asn324, 
were made flexible during docking runs. The Lamarckian genetic algorithm (LGA) was adopted to perform molecular docking along with the following docking parameters: 100 individuals in a population with a maximum of 15 million energy evaluations and a maximum of 37,000 generations, followed by 300 iterations of Solis and Wets local search. A total of 100 docking runs was performed for each calculation. The loops missing in the crystallographic structures used in this study were modelled with the MODELLER v9.11 program [34]. Representative CBD/OX1R and CBD/OX2R complexes were completed by the addition of all hydrogen atoms and underwent energy minimization. The energyminimized complexes were embedded in a POPC bilayer using charmmgui web-interface and then molecular dynamics (MD) simulations in membrane environment were carried out with pmemd.cuda module of Amber16 package [35], using lipid 14 (lipids), ff14SB force (protein) [36], and gaff (ligand) [37] force field parameterization. MD production runs were carried out for 100-200 ns. The Cpptraj module of AmberTools16 and program UCSF Chimera 1.10.1 [38] were used to perform MD analysis and to draw the figures, respectively.

\section{Results and Discussion}

The molecular mechanisms responsible for the complex pharmacology of phytocannabinoids in general, including CBD, are still far from being fully understood. Since CBD has received attention for the treatment of drug addiction [12], we considered the orexin receptors as putative molecular targets for this phytocannabinoid. Indeed, biochemical and pharmacological studies [39,40] showed that not only does a cross-talk exist between the endocannabinoid and the hypocretinergic systems, but also that $\mathrm{CB}_{1} \mathrm{R}$ and OX1R receptors form heterodimers, suggesting a synergistic or a mutual modulatory role in common physiopathological functions. In this study, we investigated whether CBD acts as a ligand of orexin receptors.

\subsection{Radioligand Binding Assay}

The affinity of CBD for both OX1R and OX2R was tested on CHO cells overexpressing either receptor. As described by the four-parameter logistic fit (Figure 1), CBD displaced [ $\left.{ }^{125} \mathrm{I}\right]$ OX-A binding at the OX1R in a concentration-dependent manner with a $\mathrm{K}_{\mathrm{i}}$ of $1.58 \pm 0.2 \mu \mathrm{M}$. However, at OX2Rs, CBD was able to only partially $(28.0+/-8.3 \%)(n=3)$ displace such binding at the highest concentration examined $(10 \mu \mathrm{M})$. Thus, radioligand binding assay showed that CBD selectively binds to OX1R with a $\mathrm{K}_{\mathrm{i}}$ of $1.58 \pm 0.2 \mu \mathrm{M}$, a value very close to the clinically achieved concentration (healthy volunteers who received CBD oral solution $\sim 21.4 \mathrm{mg} / \mathrm{kg} /$ day for six days achieved a plasma Cmax of $330.3 \mathrm{ng} / \mathrm{mL}$, which equates to $1.04 \mu \mathrm{M})$ [41].

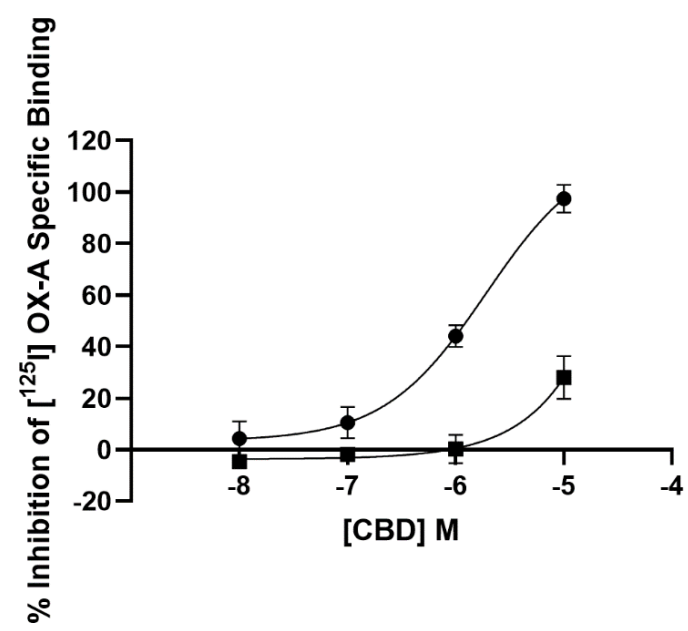

Figure 1. Competition for $\left[{ }^{125} \mathrm{I}\right]$ orexin-A binding to OX1R-CHO cells (filled circle) and OX2R-CHO cells (filled square) by CBD. Data are the mean of three independent experiments; vertical lines show standard deviation. 


\subsection{Calcium Mobilization Assay}

$\mathrm{Ca}^{2+}$ elevations in OX1-CHO cells were measured using the fluorescent $\mathrm{Ca}^{2+}$ indicator Fluo-4. Preincubation (5 min) of OX1R-CHO cells with different doses of CBD, followed by incubation with OX-A $(100 \mathrm{nM})$ in $1.5 \mathrm{mM}$ of extracellular $\mathrm{Ca}^{2+}$, caused inhibition of the $\mathrm{Ca}^{2+}$ elevation due to OX1R response to OX-A. The corresponding dose-inhibition curve is reported in Figure 2 and showed an $\mathrm{IC}_{50}$ value of $4.2 \pm 0.2 \mu \mathrm{M}(n=5)$. The OX1R antagonist SB334867 at $10 \mu \mathrm{M}$ was used as a reference compound to assess the specificity of the antagonist activity of $\mathrm{CBD}$ and the inhibition graph is shown in Figure 3. We also tested CBD and OXA in not-transfected CHO cells. In both transfected and not transfected $\mathrm{CHO}$ cells $\mathrm{CBD}$ caused a slight but significant elevation of intracellular calcium. This effect has been previously reported in several cell types and appears to be independent of direct interaction with $\mathrm{Gq}[42,43]$.

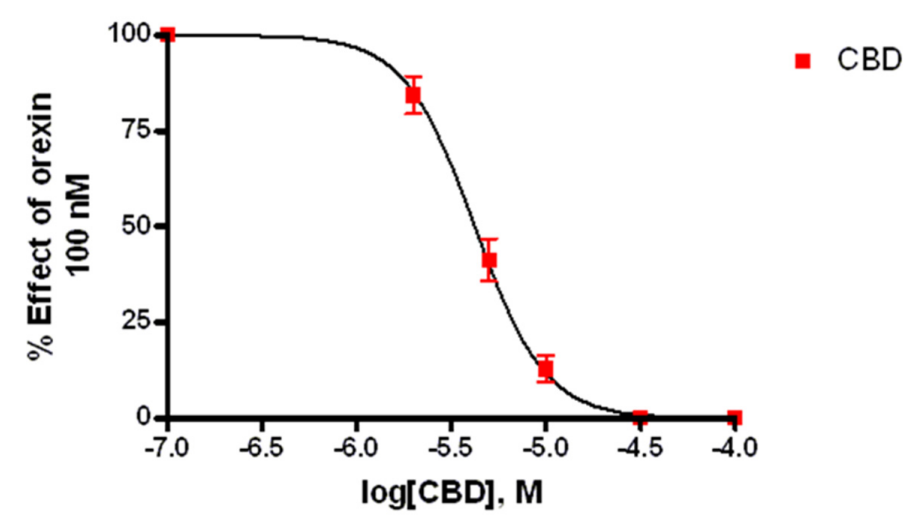

Figure 2. Effect of CBD on $\mathrm{Ca}^{2+}$ elevation induced by $100 \mathrm{nM}$ OX-A in $\mathrm{CHO}$ cells overexpressing OX1R. Data (mean \pm SEM of five independent experiments) are expressed as a percent of the maximal effect observed with OX-A alone (see Figure 3); vertical lines show SEM.

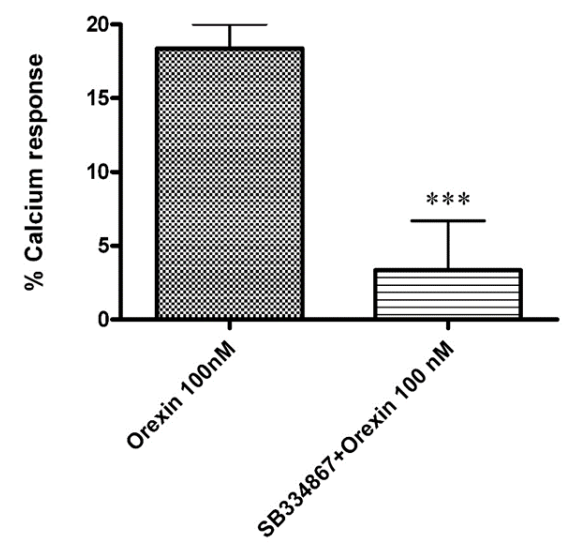

Figure 3. Effect of the OX1R antagonist SB334867 $(10 \mu \mathrm{M})$ on the $\mathrm{Ca}^{2+}$ elevation induced by OX-A $(100 \mathrm{nM})$ in CHO cells overexpressing OX1R. Data are expressed as means $\pm \mathrm{SEM},(n=4) .{ }^{* * *} p<0.01$.

\subsection{Calcium Imaging}

3.3.1. OX-A Increases Intracellular $\left[\mathrm{Ca}^{2+}\right]_{\mathrm{i}}$ in $\mathrm{CHO}$ Cells Stably Expressing OX1R or OX2R

OX1R-CHO or OX2R-CHO cells were used for $\left[\mathrm{Ca}^{2+}\right]_{i}$ measurements with fFura-2 fluorescence imaging. OX-A was used at a concentration of $200 \mathrm{nM}$ (chosen according to the effective doses used in our previous study [40]). This concentration of OX-A induced a $\left[\mathrm{Ca}^{2+}\right]_{i}$ increase with a peak of $\left[\mathrm{Ca}^{2+}\right]_{i}$ significantly higher than the basal $\left[\mathrm{Ca}^{2+}\right]_{i}$, both in OX1R-CHO (peak $\left[\mathrm{Ca}^{2+}\right]_{\mathrm{i}}: 81.5 \pm 6.1 \mathrm{nM}$ vs. basal $\left[\mathrm{Ca}^{2+}\right]_{\mathrm{i}}: 7.3 \pm 1.6 \mathrm{nM} ; p<0.001$ ) and OX2R-CHO (peak $\left[\mathrm{Ca}^{2+}\right]_{\mathrm{i}}: 80.1 \pm 5.7 \mathrm{nM}$ vs. basal $\left.\left[\mathrm{Ca}^{2+}\right]_{\mathrm{i}}: 9.1 \pm 1.8 \mathrm{nM} ; p<0.001\right)$ cells. OX-A-induced $\left[\mathrm{Ca}^{2+}\right]_{\mathrm{i}}$ increase took place in a fast manner (50-60 s), as shown in a 
representative graph referred to a randomly recorded single $\mathrm{CHO}$ cell stably expressing OX1R (Figure 4A) or OX2R (Figure 5A). The CHO cells stably expressing OX1R did not show $\left[\mathrm{Ca}^{2+}\right]_{\mathrm{i}}$ increases in response to $200 \mathrm{nM}$ OXA applied for $180 \mathrm{~s}$ after $180 \mathrm{~s}$ of treatment with the OX1R antagonist SB334867 $(10 \mu \mathrm{M})$ in the cell medium (Figure 4B). These results indicate that OX-A directly targets OX1R to regulate $\left[\mathrm{Ca}^{2+}\right]_{i}$ increase in $\mathrm{CHO}$ cells stably expressing OX1R. As shown in Figure 5B, and in agreement with its partial antagonistic effect on OX2R, incubation of OX2R-CHO cells with SB334867 $10 \mu \mathrm{M}$ in the calciumcontaining buffer solution was able to only partially block the $\left[\mathrm{Ca}^{2+}\right]_{\mathrm{i}}$ elevation induced by $200 \mathrm{nM}$ OX-A (peak $\left[\mathrm{Ca}^{2+}\right]_{\mathrm{i}}: 25.7 \pm 3.4 \mathrm{nM}$ vs. basal $\left.\left[\mathrm{Ca}^{2+}\right]_{\mathrm{i}}: 7.1 \pm 2.6 \mathrm{nM} ; p<0.05\right)$.

\section{OX1R-transfected cells}

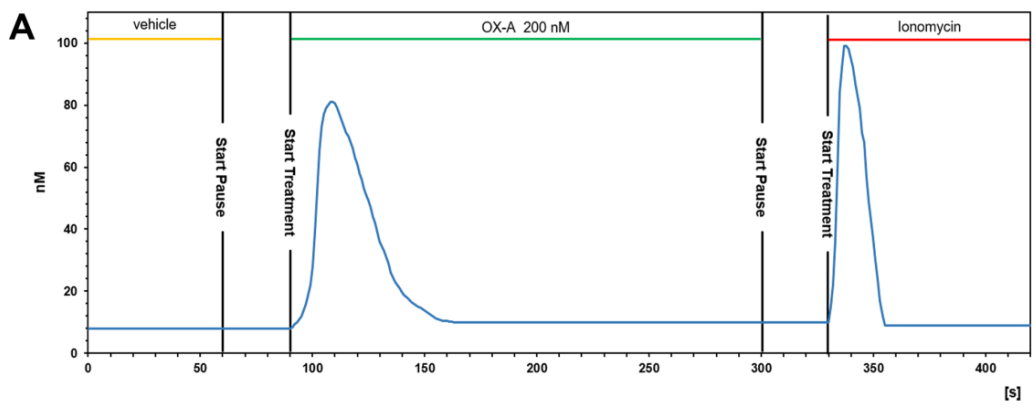

B
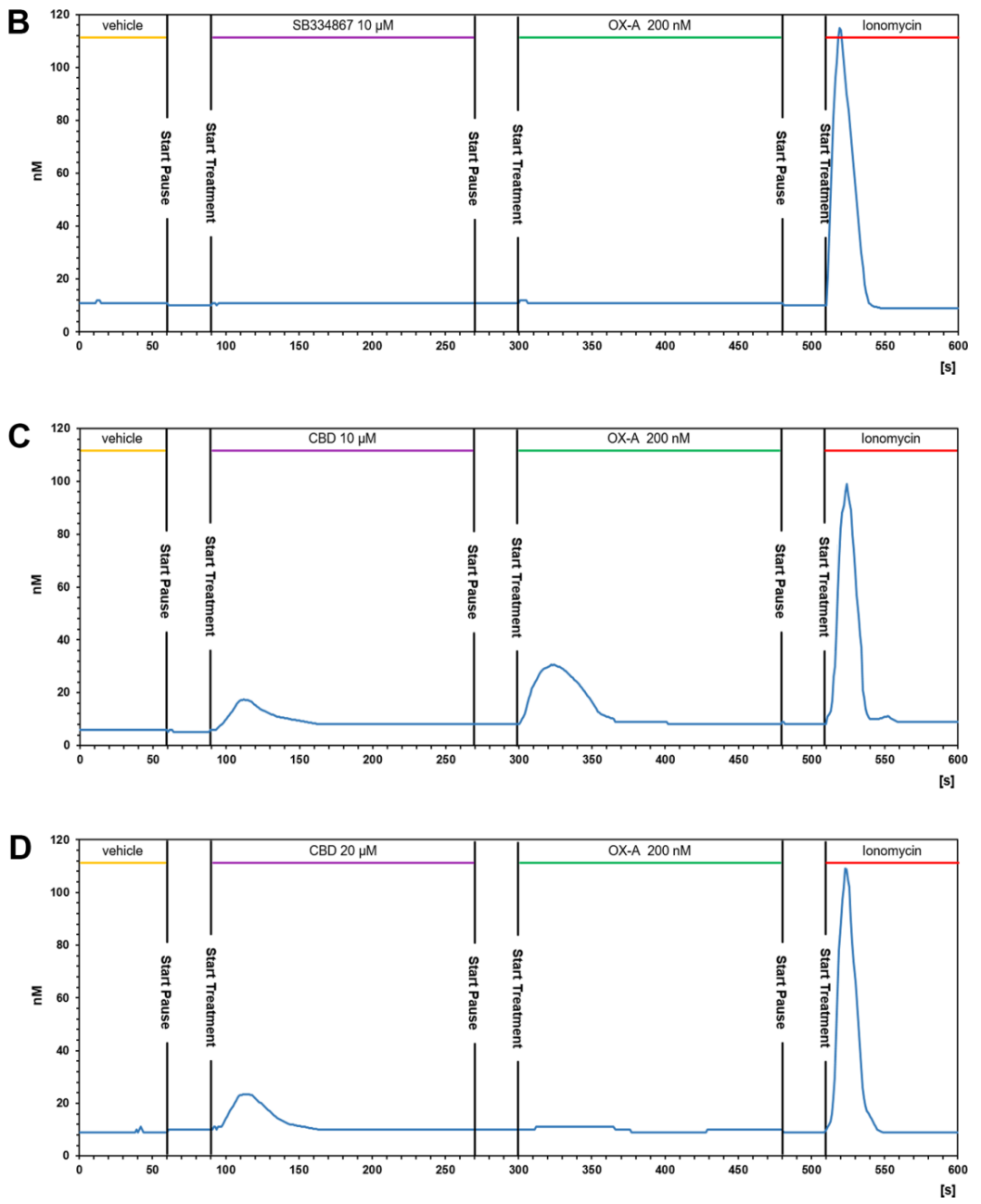

Figure 4. CBD prevents the OX-A-induced $\left[\mathrm{Ca}^{2+}\right]_{\mathrm{i}}$ response in $\mathrm{CHO}$ cells expressing OX1R. Representative traces of single-cell $\left[\mathrm{Ca}^{2+}\right]_{\mathrm{i}}$ response in Fura-2- loaded CHO cells stably expressing OX1R 
treated with $200 \mathrm{nM}$ OXA, alone or in combination with $10 \mu \mathrm{M}$ SB334867 or with $10 \mu \mathrm{M}$ or $20 \mu \mathrm{M}$ CBD, and finally with ionomycin $(2 \mu \mathrm{M})$. Images, collected continuously for $420 \mathrm{~s}(\mathbf{A}, \mathbf{B})$ or $600 \mathrm{~s}(\mathbf{C}, \mathbf{D})$, were analyzed by the Leica MetaMorph software for calcium imaging to quantify the intracellular $\left[\mathrm{Ca}^{2+}\right]_{\mathrm{i}}$ increase expressed as 340/387 $\mathrm{nm}$ excitation ratio between calcium-bound Fura-2 (green cells) and calcium-free Fura-2 (red cells). (A) $200 \mathrm{nM} \mathrm{OX-A}$ increases $\left[\mathrm{Ca}^{2+}\right]_{\mathrm{i}}$ in cells. (B) The OX1R antagonist SB334867 prevents the OX-A-induced $\left[\mathrm{Ca}^{2+}\right]_{i}$ enhancement in the cells. OX-A-responsive cells became partially (C) or completely (D) unresponsive to $200 \mathrm{nM}$ OXA after treatment with $10 \mu \mathrm{M}$ or $20 \mu \mathrm{M}$ CBD, respectively.

\section{OX2R-transfected cells}
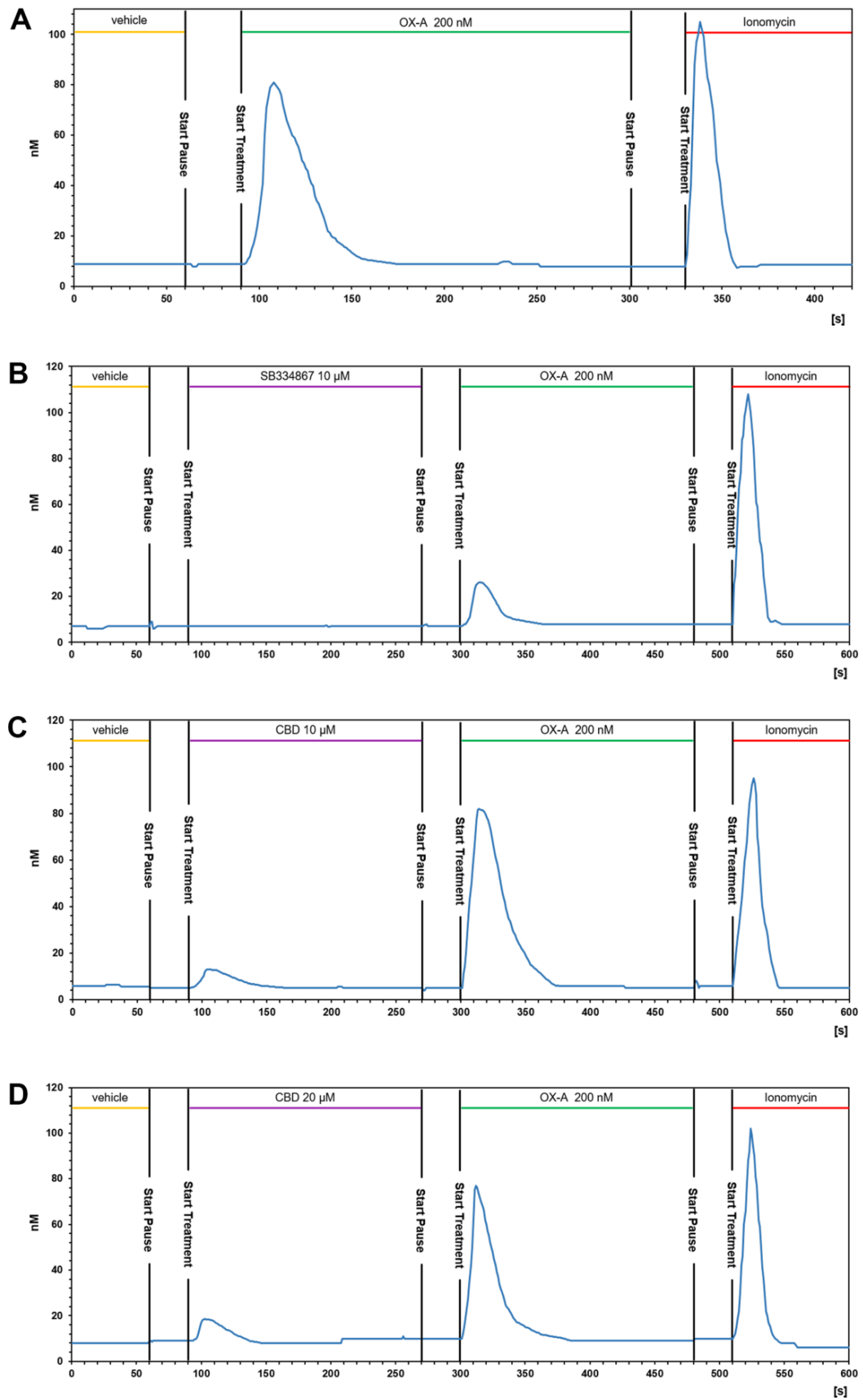

Figure 5. $\mathrm{CBD}$ does not alter the $\mathrm{OX}-\mathrm{A}$-induced $\left[\mathrm{Ca}^{2+}\right]_{\mathrm{i}}$ increase in $\mathrm{CHO}$ cells stably transfected with OX2R. Representative traces of single-cell $\left[\mathrm{Ca}^{2+}\right]_{i}$ response in Fura-2- loaded CHO cells stably overexpressing OX2R and treated with $200 \mathrm{nM}$ OXA, alone or in combination with $10 \mu \mathrm{M}$ SB334867 or 
with $10 \mu \mathrm{M}$ or $20 \mu \mathrm{M}$ CBD Ionomycin $(2 \mu \mathrm{M})$ was added at the end of the experiment. Images, collected continuously for $420 \mathrm{~s}$ (A,B) or $600 \mathrm{~s}$ (C,D), were analyzed by the Leica MetaMorph software for calcium imaging to quantify the intracellular $\left[\mathrm{Ca}^{2+}\right]_{i}$ increase expressed as $340 / 387 \mathrm{~nm}$ excitation ratio between calcium-bound Fura-2 (green cells) and calcium-free Fura-2 (red cells). (A) $200 \mathrm{nM}$ OX-A increases $\left[\mathrm{Ca}^{2+}\right]_{i}$ in cells. (B) The OX1R antagonist SB334867 prevents the OX-A-induced $\left[\mathrm{Ca}^{2+}\right]_{\mathrm{i}}$ enhancement in the cells. (C,D) Treatment with $20 \mu \mathrm{M}$ or $10 \mu \mathrm{M}$ CBD, respectively, has no effect on the increase of $\left[\mathrm{Ca}^{2+}\right]_{i}$ induced by OX-A.

\subsubsection{CBD Inhibits the $\mathrm{Ca}^{2+}$ Response Induced by OX-A in OX1R, but Not in OX2R Transfected CHO Cells}

The presence of CBD $10 \mu \mathrm{M}$ or $20 \mu \mathrm{M}$ for $\sim 3 \mathrm{~min}$ in the calcium-containing extracellular solution (see methods section) of $\mathrm{CHO}$ cells stably expressing OX1R caused a slight enhancement of $\left[\mathrm{Ca}^{2+}\right]_{\mathrm{i}}$ and was able to reduce $(10 \mu \mathrm{M})$ or prevent $(20 \mu \mathrm{M})$ the $\left[\mathrm{Ca}^{2+}\right]_{\mathrm{i}}$ increase induced by $200 \mathrm{nM}$ OX-A (Figure 4C,D). As shown in Figure 4C, $10 \mu \mathrm{M}$ CBD induced a slight $\left[\mathrm{Ca}^{2+}\right]_{\mathrm{i}}$ peak $\left(\left[\mathrm{Ca}^{2+}\right]_{\mathrm{i}}: 18.1 \pm 2.7 \mathrm{nM}\right.$ vs. basal $\left.\left[\mathrm{Ca}^{2+}\right]_{\mathrm{i}}: 6 \pm 1.2 \mathrm{nM} ; p<0.05\right)$ and reduced the increment of $\left[\mathrm{Ca}^{2+}\right]$ induced by subsequent treatment with $\mathrm{OX}-\mathrm{A}\left(\left[\mathrm{Ca}^{2+}\right]_{\mathrm{i}}\right.$ : $30.5 \pm 3.6 \mathrm{nM}$ vs. basal $\left.\left[\mathrm{Ca}^{2+}\right]_{\mathrm{i}}: 6 \pm 1.2 \mathrm{nM} ; p<0.05\right)$. Pretreatment with $20 \mu \mathrm{M} \mathrm{CBD}$ increased the $\left[\mathrm{Ca}^{2+}\right]$ (peak $\left[\mathrm{Ca}^{2+}\right]_{\mathrm{i}}: 23.7 \pm 2.9 \mathrm{nM}$ vs. basal $\left.\left[\mathrm{Ca}^{2+}\right]_{\mathrm{i}}: 8.9 \pm 1.3 \mathrm{nM} ; p<0.05\right)$, but the $\left[\mathrm{Ca}^{2+}\right]_{\mathrm{i}}$ recorded in cells with $200 \mathrm{nM} \mathrm{OX-A}$ after CBD treatment was similar to the basal levels (10.8 $\pm 2.2 \mathrm{nM}$ for OX-A vs. $8.9 \pm 1.3 \mathrm{nM}$ for the vehicle-treated cells; $p>0.05)$ (Figure 4D). These results suggest that CBD acts as OX1R antagonist.

On the contrary, pretreatment with $10 \mu \mathrm{M}$ or $20 \mu \mathrm{M}$ CBD of CHO cells stably expressing OX2R did not inhibit the $\mathrm{Ca}^{2+}$ response induced by $200 \mathrm{nM}$ OX-A. As shown in Figure $5 \mathrm{C}, \mathrm{D}, \mathrm{CBD}$ induced elevation of $\left[\mathrm{Ca}^{2+}\right]_{\mathrm{i}}$ in a concentration-dependent manner $(12.2 \pm 1.3 \mathrm{nM}$ for CBD $10 \mu \mathrm{M}$ vs. basal level: $5.8 \pm 1.6 \mathrm{nM} ; 17.9 \pm 2.3 \mathrm{nM}$ for CBD $20 \mu \mathrm{M}$ vs. basal level: $7.9 \pm 1.9 \mathrm{nM} ; p<0.05$ ), whereas the addition of OX-A in the same cell medium after $180 \mathrm{~s}$ of CBD treatment induced a $\left[\mathrm{Ca}^{2+}\right]_{\mathrm{i}}$ enhancement with a peak of $\left[\mathrm{Ca}^{2+}\right]_{\mathrm{i}}$ significantly higher than the basal $\left[\mathrm{Ca}^{2+}\right]_{\mathrm{i}}\left(\left[\mathrm{Ca}^{2+}\right]_{\mathrm{i}}: 82.3 \pm 5.9 \mathrm{nM}\right.$ after CBD $10 \mu \mathrm{M}$ vs. basal level: $5.8 \pm 1.6 \mathrm{nM} ; 77.5 \pm 6.3 \mathrm{nM}$ after CBD $20 \mu \mathrm{M}$ vs. basal level: $7.9 \pm 1.9 \mathrm{nM} ; p<0.001)$. The elevation of $\left[\mathrm{Ca}^{2+}\right]_{\mathrm{i}}$ induced by $\mathrm{CBD}$, as already observed in calcium mobilization assay, is not due to OXRs, since it also occurs in non-transfected cells (see Figure 6).

\section{Not-transfected cells}

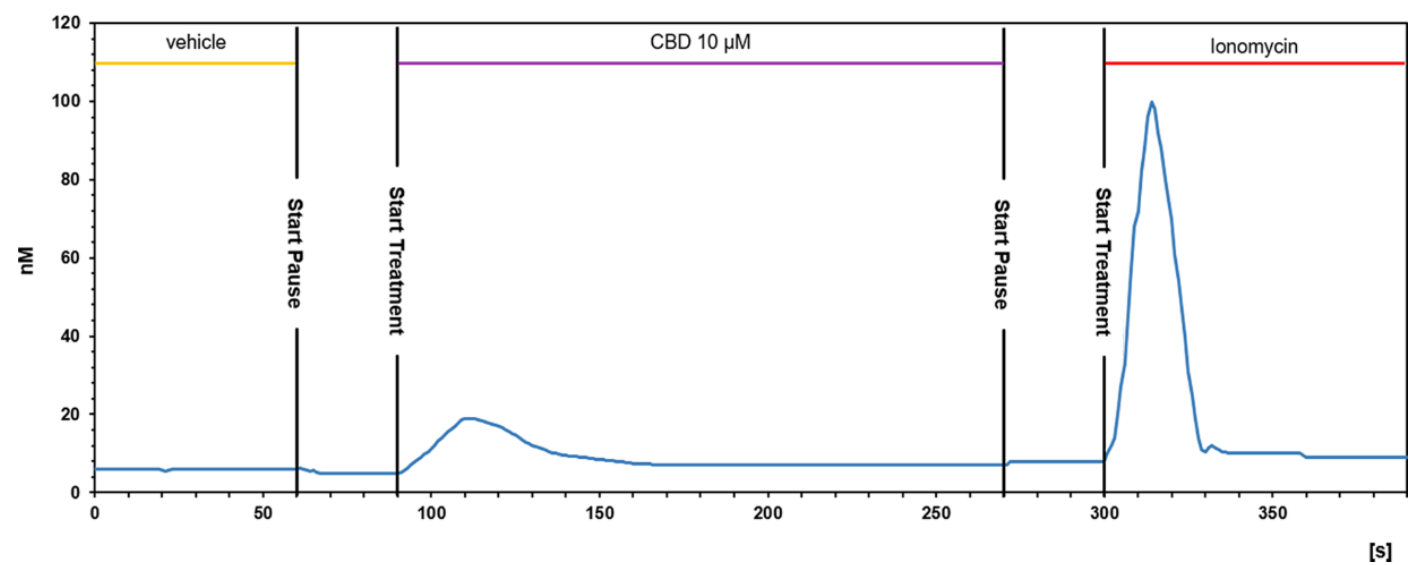

Figure 6. $\mathrm{CBD}$ induces a slight $\left[\mathrm{Ca}^{2+}\right]_{\mathrm{i}}$ increase in not-transfected $\mathrm{CHO}$ cells. Representative traces of single-cell $\left[\mathrm{Ca}{ }^{2+}\right]_{\mathrm{i}}$ response in Fura-2- loaded not-transfected CHO cells. Ionomycin $(2 \mu \mathrm{M})$ was added at the end of the experiment. Images, collected continuously for $390 \mathrm{~s}$, were analyzed by the Leica MetaMorph software for calcium imaging to quantify the intracellular $\left[\mathrm{Ca}^{2+}\right]_{i}$ increase expressed as $340 / 387 \mathrm{~nm}$ excitation ratio between calcium-bound Fura-2 (green cells) and calcium-free Fura-2 (red cells). 
Collectively, the functional assays carried out by both intracellular $\mathrm{Ca}^{2+}$ measurements and $\mathrm{Ca}^{2+}$ imaging showed that CBD is an OX1R antagonist at low micromolar concentrations and is selective for OX1R over OX2R.

\subsection{OX1R/CBD Theoretical Complex}

Next, a comparative study of molecular docking and molecular dynamics simulations (MD) in membrane environment (up to $200 \mathrm{~ns}$ ) of CBD in complex with either OX1R or OX2R was undertaken to shed light on the binding mode of CBD in the binding site of OX1R and to rationalize CBD selectivity toward this receptor over OX2R. From docking runs of CBD into the OX1R binding site, four starting poses were selected for the subsequent MD on the basis of binding energy and ability to interact with residues known to be relevant for receptor binding and, among these, three final poses, termed I, II, and III, were stable to MD in terms of root-mean-square-deviation (rmsd). The first two poses shared a similar arrangement, only differing for a slight rotation of the CBD aromatic ring. However, since only pose I formed a stable H-bond with Ser $103^{2.61}$, pose II was discarded from subsequent analysis. In pose I, the terpenoid ring interacted with Pro123 3.29 , a residue involved in ligand interactions also in experimentally determined complex structures, while the pentanoyl chain pointed toward Phe219.42. In pose III CBD adopted a reverse orientation with respect to pose I, with the pentanoyl chain pointing toward the receptor N-terminal end and the terpenoid ring pointing toward Ala127 3.33 , Tyr215 $5^{5.38}$, and Phe219 ${ }^{5.42}$. Pose I and III, representative of the possible binding modes of CBD within the orthosteric binding site of OX1R, are shown in Figure 7, panel a and b, respectively. It is noteworthy that OX1R residues interacting with CBD have been previously characterized as being important for antagonist binding to this receptor [25].

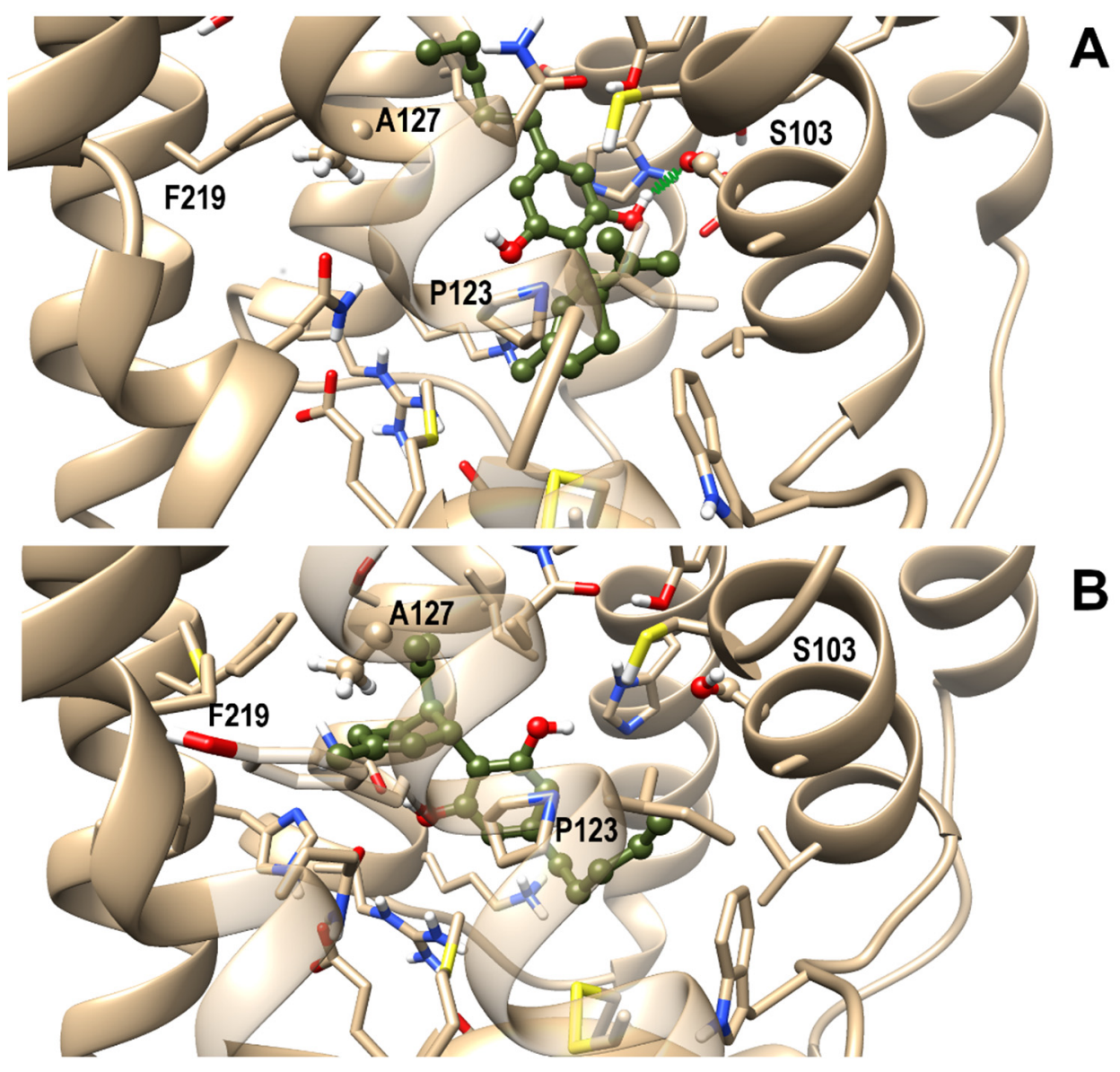

Figure 7. Representative frames from MD of CBD/OX1R complexes: Pose I (A) and III (B). A ball and stick representation is used for heavy atoms plus polar hydrogens of ligand, whereas a stick representation 
was used for protein sidechains within $5 \AA$ from the ligand. Protein carbon atoms are colored in tan according to ribbon for protein and olive drab for the ligand. Hydrogen, nitrogen, oxygen, and sulfur atoms are painted white, blue, red and yellow, respectively. A transparent surface for ribbons is used whenever they hide the ligand. A "green spring" style is adopted for H-bonds involving ligand atoms.

A best-fit superposition of protein backbones between CBD poses I/III and the x-ray structure of the OX1R in complex with the antagonist suvorexant (Figure 8, panels A and $B$, respectively) shows that, when overlapping the two ligand poses, CBD globally spans the same spatial region occupied by suvorexant, each pose filling about one-half of the volume of the bulkier suvorexant. Hence, the reduced occupancy of the binding site and the higher flexibility of CBD in comparison to suvorexant account for CBD's lower potency vs. suvorexant $\left(\mathrm{K}_{\mathrm{i}} 0.55 \mathrm{nM}\right)[44]$.

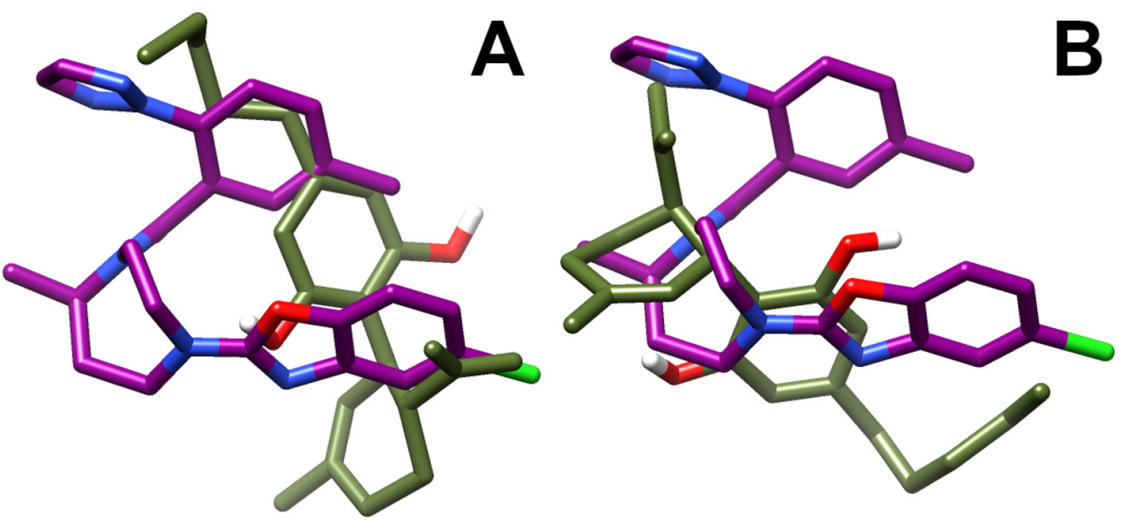

Figure 8. Best-fit superposition of protein backbones between CBD poses I (A)/III (B) and the x-ray structure of the OX1R-suvorexant complex. Only the ligands are shown for clarity and drawn in stick representation. The suvorexant is colored in deep purple and the CBD in olive drab. Hydrogen, nitrogen, oxygen, and fluorine atoms are painted white, blue, red and green, respectively.

To assess if the arrangements found for CBD could also be conserved in OX2R, the same starting poses I and III were used for MD of CBD/OX2R complexes. The first pose was also found as the best docking pose in OX2R whereas pose III was not found, due to steric clashes with Thr135 3.33 . Trajectory analysis, reported in Figure 9, showed that neither pose I, nor pose III resulted in stable OX2R, thus explaining the receptor selectivity of CBD toward OX1R.
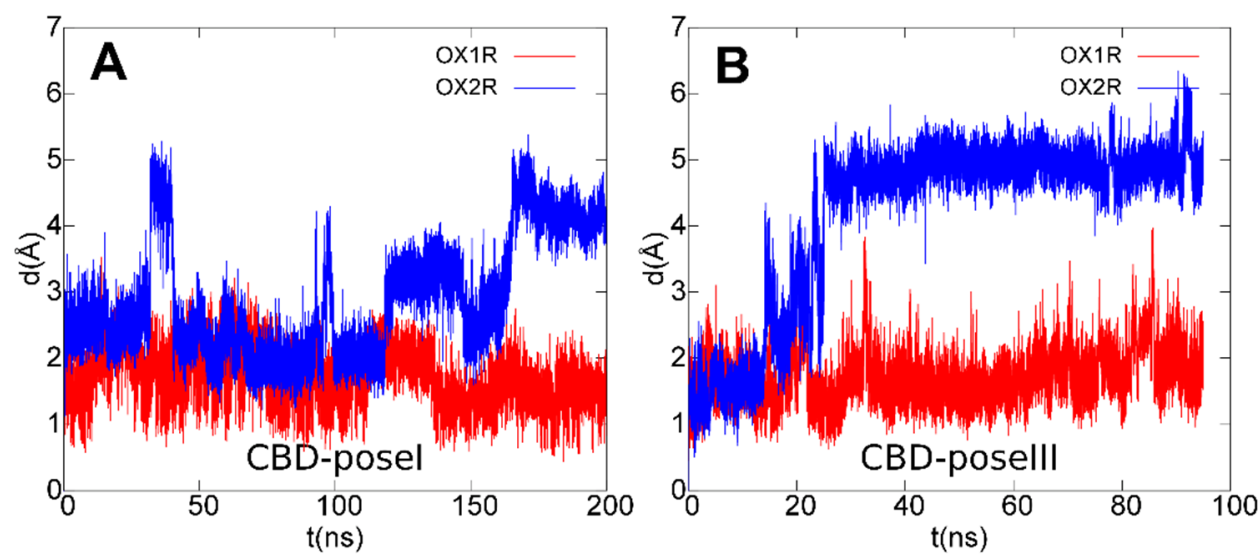

Figure 9. Root mean square deviation (rmsd) plots of CBD ligand in poses I (A)/III (B) during the last $200 \mathrm{~ns}$ (A)/95 ns (B) of MD simulations after best-fit of protein backbone in OX1R (red) and OX2R (blue). 
In fact, among the contacting residues in the OX1R binding site, CBD formed stable interactions with the only two non-conserved residues between OX1R and OX2R, that is OX1R Ser103 2.61 (pose I) and OX1R Ala127 $7^{3.33}$ (pose III), both replaced by a bulkier threonine residue in OX2R, which contributed to the destabilization of the CBD-OX2R complex during MD simulations, in agreement with the results from the binding assays. Furthermore, the docking/MD study identified a protein-ligand interaction network involving OX1R residues reported to be critical for antagonist binding, in agreement with the experimental validation.

\section{Conclusions}

In summary, we identified CBD as a selective OX1R antagonist and such effect could contribute to explaining, for example, the anorexigenic effect exerted by CBD reported in some studies [45], since OX1R is localized in appetite-regulating neurons in the hypothalamus [46] and it has been demonstrated that the hyperphagia induced by the centrally administrated OX-A is mediated by OX1Rs [47,48]. Moreover, the selective OX1R antagonist SB-334867 attenuates orexin-A induced feeding and has anorectic effects inducing satiety without nausea [49].

Although further studies are required to assess the clinical relevance of orexin antagonism CBD action, this study adds a new element to the complex picture of the mechanism of action of CBD and paves the way to in vivo studies fully exploring the pharmacological implications of its activity as a negative modulator of the hypocretinergic-endocannabinoid axis, for example in the treatment of substance use disorders or body weight regulation.

Author Contributions: Conceptualization, R.M.V., P.A., R.G. and V.D.; methodology, R.M.V., P.A., L.D. and L.C.; formal analysis, R.M.V., P.A., A.S.M., L.D., L.T., L.C., F.A.I., R.S. and F.P.; investigation, R.M.V., P.A., F.A.I., A.S.M., L.T., R.S., L.C. and L.D.; resources, V.D. and R.M.V.; writing-original draft preparation, R.M.V., PA., L.C., R.G. and V.D.; writing-review and editing, R.M.V., R.G. and V.D.; visualization, R.M.V., L.T., L.C. and L.D.; funding acquisition, V.D. and R.M.V. All authors have read and agreed to the published version of the manuscript.

Funding: This work was supported by a research grant from GW Research Ltd., Cambridge, United Kingdom.

Institutional Review Board Statement: Not applicable.

Informed Consent Statement: Not applicable.

Data Availability Statement: Not applicable.

Conflicts of Interest: R.M.V., F.A.I., F.P., L.C. and V.D. receive funding from GW Research Ltd., UK. R.G. and R.S. are employees of GW Research Ltd., UK. V.D. is a paid consultant to GW Research Ltd., UK.

\section{References}

1. Mandolini, G.M.; Lazzaretti, M.; Pigoni, A.; Oldani, L.; Delvecchio, G.; Brambilla, P. Pharmacological properties of cannabidiol in the treatment of psychiatric disorders: A critical overview. Epidemiol. Psychiatr. Sci. 2018, 27, 327-335. [CrossRef]

2. Ożarowski, M.; Karpiński, T.M.; Zielińska, A.; Souto, E.B.; Wielgus, K. Cannabidiol in neurological and neoplastic diseases: Latest developments on the molecular mechanism of action. Int. J. Mol. Sci. 2021, 22, 4294. [CrossRef]

3. Ibeas Bih, C.; Chen, T.; Nunn, A.V.W.; Bazelot, M.; Dallas, M.; Whalley, B.J. Molecular targets of cannabidiol in neurological disorders. Neurotherapeutics 2015, 12, 699-730. [CrossRef] [PubMed]

4. Vitale, R.M.; Iannotti, F.A.; Amodeo, P. The (Poly)pharmacology of cannabidiol in neurological and neuropsychiatric disorders: Molecular mechanisms and targets. Int. J. Mol. Sci. 2021, 22, 4876. [CrossRef] [PubMed]

5. De Petrocellis, L.; Ligresti, A.; Moriello, A.S.; Allarà, M.; Bisogno, T.; Petrosino, S.; Stott, C.G.; Di Marzo, V. Effects of cannabinoids and cannabinoid-enriched Cannabis extracts on TRP channels and endocannabinoid metabolic enzymes. Br. J. Pharmacol. 2011, 163, 1479-1494. [CrossRef]

6. Ryberg, E.; Larsson, N.; Sjögren, S.; Hjorth, S.; Hermansson, N.-O.; Leonova, J.; Elebring, T.; Nilsson, K.; Drmota, T.; Greasley, P.J. The orphan receptor GPR55 is a novel cannabinoid receptor. Br. J. Pharmacol. 2009, 152, 1092-1101. [CrossRef] [PubMed]

7. Campos, A.C.; Ferreira, F.R.; Guimarães, F.S. Cannabidiol blocks long-lasting behavioral consequences of predator threat stress: Possible involvement of 5HT1A receptors. J. Psychiatr. Res. 2012, 46, 1501-1510. [CrossRef] 
8. Kathmann, M.; Flau, K.; Redmer, A.; Tränkle, C.; Schlicker, E. Cannabidiol is an allosteric modulator at mu- and delta-opioid receptors. Naunyn. Schmiedebergs. Arch. Pharmacol. 2006, 372, 354-361. [CrossRef]

9. Laprairie, R.B.; Bagher, A.M.; Kelly, M.E.M.; Denovan-Wright, E.M. Cannabidiol is a negative allosteric modulator of the cannabinoid CB 1 receptor. Br. J. Pharmacol. 2015, 172, 4790-4805. [CrossRef]

10. Tham, M.; Yilmaz, O.; Alaverdashvili, M.; Kelly, M.E.M.; Denovan-Wright, E.M.; Laprairie, R.B. Allosteric and orthosteric pharmacology of cannabidiol and cannabidiol-dimethylheptyl at the type 1 and type 2 cannabinoid receptors. Br. J. Pharmacol. 2019, 176, 1455-1469. [CrossRef]

11. Straiker, A.; Dvorakova, M.; Zimmowitch, A.; Mackie, K. Cannabidiol inhibits endocannabinoid signaling in autaptic hippocampal neurons. Mol. Pharmacol. 2018, 94, 743-748. [CrossRef]

12. Gonzalez-Cuevas, G.; Martin-Fardon, R.; Kerr, T.M.; Stouffer, D.G.; Parsons, L.H.; Hammell, D.C.; Banks, S.L.; Stinchcomb, A.L.; Weiss, F. Unique treatment potential of cannabidiol for the prevention of relapse to drug use: Preclinical proof of principle. Neuropsychopharmacology 2018, 43, 2036-2045. [CrossRef]

13. Prud'homme, M.; Cata, R.; Jutras-Aswad, D. Cannabidiol as an intervention for addictive behaviors: A systematic review of the evidence. Subst. Abus. Res. Treat. 2015, 9, 33-38. [CrossRef] [PubMed]

14. Hurd, Y.L.; Yoon, M.; Manini, A.F.; Hernandez, S.; Olmedo, R.; Ostman, M.; Jutras-Aswad, D. Early phase in the development of cannabidiol as a treatment for addiction: Opioid relapse takes initial center stage. Neurotherapeutics 2015, 12, 807-815. [CrossRef] [PubMed]

15. Perrey, D.A.; Zhang, Y. Therapeutics development for addiction: Orexin-1 receptor antagonists. Brain Res. 2018, 9, 587-602. [CrossRef]

16. Jantti, M.H.; Putula, J.; Turunen, P.M.; Nasman, J.; Reijonen, S.; Lindqvist, C.; Kukkonen, J.P. Autocrine endocannabinoid signaling through CB1 receptors potentiates OX1 orexin receptor signaling. Mol. Pharmacol. 2013, 83, 621-632. [CrossRef] [PubMed]

17. Jäntti, M.; Putula, J.; Somerharju, P.; Frohman, M.; Kukkonen, J. OX 1 orexin/hypocretin receptor activation of phospholipase D. Br. J. Pharmacol. 2012, 165, 1109-1123. [CrossRef] [PubMed]

18. Li, J.; Hu, Z.; de Lecea, L. The hypocretins/orexins: Integrators of multiple physiological functions. Br. J. Pharmacol. 2014, 171, 332-350. [CrossRef] [PubMed]

19. Saito, Y.C.; Maejima, T.; Nishitani, M.; Hasegawa, E.; Yanagawa, Y.; Mieda, M.; Sakurai, T. Monoamines inhibit GABAergic neurons in ventrolateral preoptic area that make direct synaptic connections to hypothalamic arousal neurons. J. Neurosci. 2018, 38, 6366-6378. [CrossRef]

20. Hasegawa, E.; Yanagisawa, M.; Sakurai, T.; Mieda, M. Orexin neurons suppress narcolepsy via 2 distinct efferent pathways. J. Clin. Investig. 2014, 124, 604-616. [CrossRef]

21. Cristino, L.; Busetto, G.; Imperatore, R.; Ferrandino, I.; Palomba, L.; Silvestri, C.; Petrosino, S.; Orlando, P.; Bentivoglio, M.; Mackie, K.; et al. Obesity-driven synaptic remodeling affects endocannabinoid control of orexinergic neurons. Proc. Natl. Acad. Sci. USA 2013, 110, 2229-2238. [CrossRef]

22. Peyron, C.; Tighe, D.K.; van den Pol, A.N.; de Lecea, L.; Heller, H.C.; Sutcliffe, J.G.; Kilduff, T.S. Neurons containing hypocretin (orexin) project to multiple neuronal systems. J. Neurosci. 1998, 18, 9996-10015. [CrossRef]

23. Scammell, T.E.; Winrow, C.J. Orexin receptors: Pharmacology and therapeutic opportunities. Annu. Rev. Pharmacol. Toxicol. 2011, 51, 243-266. [CrossRef]

24. Merlo Pich, E.; Melotto, S. Orexin 1 receptor antagonists in compulsive behavior and anxiety: Possible therapeutic use. Front. Neurosci. 2014, 8, 26. [CrossRef]

25. Yin, J.; Babaoglu, K.; Brautigam, C.A.; Clark, L.; Shao, Z.; Scheuermann, T.H.; Harrell, C.M.; Gotter, A.L.; Roecker, A.J.; Winrow, C.J.; et al. Structure and ligand-binding mechanism of the human OX1 and OX2 orexin receptors. Nat. Struct. Mol. Biol. 2016, 23, 293-299. [CrossRef]

26. Yin, J.; Mobarec, J.C.; Kolb, P.; Rosenbaum, D.M. Crystal structure of the human OX2 orexin receptor bound to the insomnia drug suvorexant. Nature 2015, 519, 247-250. [CrossRef] [PubMed]

27. Iannotti, F.A.; Pagano, E.; Moriello, A.S.; Alvino, F.G.; Sorrentino, N.C.; D’Orsi, L.; Gazzerro, E.; Capasso, R.; De Leonibus, E.; De Petrocellis, L.; et al. Effects of non-euphoric plant cannabinoids on muscle quality and performance of dystrophic mdx mice. Br. J. Pharmacol. 2019, 176, 1568-1584. [CrossRef] [PubMed]

28. Grynkiewicz, G.; Poenie, M.; Tsien, R.Y. A new generation of $\mathrm{Ca}^{2+}$ indicators with greatly improved fluorescence properties. J. Biol. Chem. 1985, 260, 3440-3450. [CrossRef]

29. Hassinen, T.; Peräkylä, M. New energy terms for reduced protein models implemented in an Off-Lattice force field. J. Comput. Chem. 2001, 22, 1229-1242. [CrossRef]

30. Clark, M.; Cramer, R.D.; Van Opdenbosch, N. Validation of the general purpose tripos 5.2 force field. J. Comput. Chem. 1989, 10, 982-1012. [CrossRef]

31. Marenich, A.V.; Cramer, C.J.; Truhlar, D.G. Universal solvation model based on solute electron density and on a continuum model of the solvent defined by the bulk dielectric constant and atomic surface tensions. J. Phys. Chem. B 2009, 113, $6378-6396$. [CrossRef] [PubMed]

32. Fox, T.; Kollman, P.A. Application of the RESP methodology in the parametrization of organic solvents. J. Phys. Chem. B 1998, 102, 8070-8079. [CrossRef] 
33. Morris, G.M.; Huey, R.; Lindstrom, W.; Sanner, M.F.; Belew, R.K.; Goodsell, D.S.; Olson, A.J. AutoDock4 and AutoDockTools4: Automated docking with selective receptor flexibility. J. Comput. Chem. 2009, 30, 2785-2791. [CrossRef]

34. Eswar, N.; Webb, B.; Marti-Renom, M.A.; Madhusudhan, M.S.; Eramian, D.; Shen, M.-Y.; Pieper, U.; Sali, A. Comparative protein structure modeling using modeller. In Current Protocols in Bioinformatics; John Wiley \& Sons, Inc.: Hoboken, NJ, USA, 2006; Volume 5, pp. 5.6.1-5.6.30.

35. Götz, A.W.; Williamson, M.J.; Xu, D.; Poole, D.; Le Grand, S.; Walker, R.C. Routine microsecond molecular dynamics simulations with AMBER on GPUs. 1. generalized born. J. Chem. Theory Comput. 2012, 8, 1542-1555. [CrossRef]

36. Case, D.A.; Betz, R.M.; Cerutti, D.S.; Cheatham, T.E., III; Darden, T.A.; Duke, R.E.; Giese, T.J.; Gohlke, H.; Goetz, A.W.; Homeyer, N.; et al. AMBER; University of California: San Francisco, CA, USA, 2016.

37. Wang, J.; Wolf, R.M.; Caldwell, J.W.; Kollman, P.A.; Case, D.A. Development and testing of a general amber force field. J. Comput. Chem. 2004, 25, 1157-1174. [CrossRef] [PubMed]

38. Pettersen, E.F.; Goddard, T.D.; Huang, C.C.; Couch, G.S.; Greenblatt, D.M.; Meng, E.C.; Ferrin, T.E. UCSF Chimera-A visualization system for exploratory research and analysis. J. Comput. Chem. 2004, 25, 1605-1612. [CrossRef] [PubMed]

39. Flores, Á.; Maldonado, R.; Berrendero, F. Cannabinoid-hypocretin cross-talk in the central nervous system: What we know so far. Front. Neurosci. 2013, 7, 256. [CrossRef] [PubMed]

40. Imperatore, R.; Palomba, L.; Morello, G.; Spiezio, A.D.; Piscitelli, F.; Marzo, V.D.; Cristino, L. Formation of OX-1R/CB 1 $\mathrm{R}$ heteromeric complexes in embryonic mouse hypothalamic cells: Effect on intracellular calcium, 2-arachidonoyl-glycerol biosynthesis and ERK phosphorylation. Pharmacol. Res. 2016, 111, 600-609. [CrossRef]

41. Taylor, L.; Gidal, B.; Blakey, G.; Tayo, B.; Morrison, G. A phase I, randomized, double-blind, placebo-controlled, single ascending dose, multiple dose, and food effect trial of the safety, tolerability and pharmacokinetics of highly purified cannabidiol in healthy subjects. CNS Drugs 2018, 32, 1053-1067. [CrossRef]

42. Eubler, K.; Herrmann, C.; Tiefenbacher, A.; Köhn, F.-M.; Schwarzer, J.; Kunz, L.; Mayerhofer, A. Ca ${ }^{2+}$ signaling and IL-8 secretion in human testicular peritubular cells involve the cation channel TRPV2. Int. J. Mol. Sci. 2018, 19, 2829. [CrossRef]

43. Olivas-Aguirre, M.; Torres-López, L.; Valle-Reyes, J.S.; Hernández-Cruz, A.; Pottosin, I.; Dobrovinskaya, O. Cannabidiol directly targets mitochondria and disturbs calcium homeostasis in acute lymphoblastic leukemia. Cell Death Dis. 2019, 10, 779. [CrossRef] [PubMed]

44. Cox, C.D.; Breslin, M.J.; Whitman, D.B.; Schreier, J.D.; McGaughey, G.B.; Bogusky, M.J.; Roecker, A.J.; Mercer, S.P.; Bednar, R.A.; Lemaire, W.; et al. Discovery of the dual orexin receptor antagonist [(7 R)-4-(5-Chloro-1,3-benzoxazol-2-yl)-7-methyl-1,4-diazepan1-yl][5-methyl-2-(2H -1,2,3-triazol-2-yl)phenyl] methanone (MK-4305) for the treatment of insomnia. J. Med. Chem. 2010, 53, 5320-5332. [CrossRef] [PubMed]

45. Ignatowska-Jankowska, B.; Jankowski, M.M.; Swiergiel, A.H. Cannabidiol decreases body weight gain in rats: Involvement of CB2 receptors. Neurosci. Lett. 2011, 490, 82-84. [CrossRef]

46. Bäckberg, M.; Hervieu, G.; Wilson, S.; Meister, B. Orexin receptor-1 (OX-R1) immunoreactivity in chemically identified neurons of the hypothalamus: Focus on orexin targets involved in control of food and water intake. Eur. J. Neurosci. 2002, 15, 315-328. [CrossRef]

47. Rodgers, R.J.; Halford, J.C.G.; de Nunes Souza, R.L.; de Canto Souza, A.L.; Piper, D.C.; Arch, J.R.S.; Upton, N.; Porter, R.A.; Johns, A.; Blundell, J.E. SB-334867, a selective orexin-1 receptor antagonist, enhances behavioural satiety and blocks the hyperphagic effect of orexin-A in rats. Eur. J. Neurosci. 2001, 13, 1444-1452. [CrossRef] [PubMed]

48. Haynes, A.C.; Jackson, B.; Overend, P.; Buckingham, R.E.; Wilson, S.; Tadayyon, M.; Arch, J.R. Effects of single and chronic intracerebroventricular administration of the orexins on feeding in the rat. Peptides 1999, 20, 1099-1105. [CrossRef]

49. Ishii, Y.; Blundell, J.; Halford, J.; Upton, N.; Porter, R.; Johns, A.; Jeffrey, P.; Summerfield, S.; Rodgers, R. Anorexia and weight loss in male rats $24 \mathrm{~h}$ following single dose treatment with orexin-1 receptor antagonist SB-334867. Behav. Brain Res. 2005, 157, 331-341. [CrossRef] [PubMed] 